\title{
BENTUK DAN PERILAKU FRASA VERBA NOMINA DALAM BAHASA ARAB
}

\author{
Arifuddin \\ arifuddin@staff.uns.ac.id \\ Program Studi Sastra Arab Fakultas Ilmu Budaya \\ Universitas Sebelas Maret Surakarta
}

\begin{abstract}
Verbal noun phrase (VNP) is a component of the construct phrase or idhäfah. This study aims to describe VNP's structure and behavior in arabic grammar and show the unique characteristics of VNP among other types of construct phrase. The methodology used in this study is qualitative descriptive. The data containing VNP is collected from several sources i.e The Quran, Prophetic tradition, and online newspaper. The analysis of data is occurred by distributional methode in which bases its performance on analysing each linguistic particular related to other units. The results state that VNP has distinctive form: the first term mudhāf is a verbal noun which has neither the definite article nor nunation, and second term is definite or indefinite noun with no prepositional insertion. In order to syntac relation built by VNP the second term is the agent or doer of the action conveid by verbal noun, or the object of an action.
\end{abstract}

Keywords: Genitive construct, verbal noun phrase, agent relationship, object relationship.

$$
\begin{aligned}
& \text { ملخص } \\
& \text { تمثل العبارة المصدرية نوعا من التركيب الإضافف فن اللغة العربية ـ هذا البحث يهدف إلى وصف تركيب العبارة } \\
& \text { المصدرية ونصرفاتا النحوية والدلالية ، وإثبات خصائصها المميزة عن سائر أنماط التركيب الإضافى لـ ويستخدم }
\end{aligned}
$$

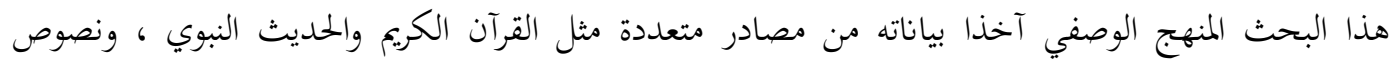

$$
\begin{aligned}
& \text { الأخبار اليومية الإلكترونية ـ وطريقة التحليل المستخدمة طريقة توزيعية وهي طريقة تحليلية تعتمد على تصرفات }
\end{aligned}
$$

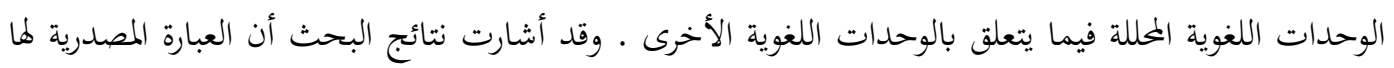

$$
\begin{aligned}
& \text { تركيب خاص من أنماط التركيب الإضاف الأخرى ، هذا النمط هو أن المضاف من جنس اسم المات المصدر النكرة }
\end{aligned}
$$

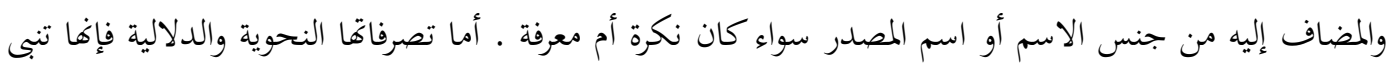

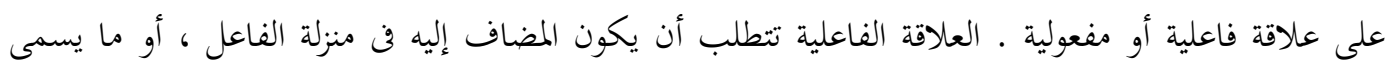

$$
\begin{aligned}
& \text { بإضافة المصدر لفاعله ، والعلاقة المفعولة تتطلب أن يكون المضاف إليه فن منزلة المفعول به ، أو ما يسمى بإضافة } \\
& \text { المصدر لمفعوله . }
\end{aligned}
$$$$
\text { الكلمات المفتاحية : الإضافة ، العبارة المصدرية ، علاقة الفاعلية ، علاقة المفعولية . }
$$ 


\section{PENDAHULUAN}

Dalam kajian sintaksis, frasa (phrase) merupakan satuan bahasa yang terdiri atas dua kata atau lebih yang tidak membentuk relasi predikatif. Sebagai satuan bahasa yang menempati level di atas kata dan di bawah klausa, frasa memiliki peran penting dalam teks atau wacana kebahasaan. Dari sisi kuantitas, frasa memuat sejumlah kata yang terikat dalam satu kaidah struktur frasa dan mendominasi sebagai pengisi fungsi sintaksis. Sedangkan dari sisi kualitas, frasa memainkan peran sesuai fungsi sintaksis yang direpresentasikan. Berdasarkan jenisnya pula, komposisi kata ini memiliki makna gramatikal yang sangat menentukan dalam pemahaman teks bacaan

Bahasa Arab yang dikenal sebagai bahasa religius dalam kaitannya dengan teks Al-Quran dan hadis Nabi Muhammad SAW, bekerja dalam mekanisme gramatika yang sistematis, ketat dan logis. Sebagai contoh, dalam tataran morfologi atau pembentukan kata, bahasa Arab menggunakan pola-pola baku (wazan) yang harus diikuti dalam pembentukan nomina dan verba. Hanya sedikit saja dari populasi kosakata bahasa yang pembentukannya tidak mengikuti polapola tersebut. Fenomena ini dinamai sebagai bentuk penyimpangan (syādz/irregular) yang diasumsikan pasti ada dalam setiap bahasa. Demikian juga pada tataran sintaksis, rangkaian kata dalam kalimat diikat oleh relasi gramatikal yang sistematis dan logis. Selain itu, tata bahasa Arab mendasarkan struktur sintaksisnya atas persesuaian (agreement) antar satuan pembentuknya.

Frasa sebagai satuan kebahasaan dalam gramatika Arab tradisional tidak dikenal secara defnitif. Satuan kebahasaan yang banyak dikupas dalam referensi gramatika Arab tradisional adalah kata (kalimah) dan klausa atau kalimat (kalām atau jumlah). Ibnu Ya'īsy (2001: I/70) membahas keduanya di permulaan kitab Syarchu al-Mufashshal, kalimah adalah lafal yang menunjukkan arti tunggal, sedangkan kalām adalah komposisi dua kata atau lebih yang memiliki hubungan predikatif $(i s n \bar{a} d)$. Kalām juga disebut jumlah. Meskipun demikian, secara fakta kebahasaan ada sejumlah konstruksi yang dapat dikategorikan sebagai frasa dalam perspektif gramatika Arab modern. Diantaranya yang paling banyak dikenal adalah konstruksi na't man 'ùt (adjectival phrase) dan konstruksi iḍāfah (annexation).

Persinggungan gramatika Arab dengan kajian linguistik umum yang berkembang di dunia Barat membawa terminologi frasa menjadi judul pembahasan dalam gramatika Arab modern. Penggunaan terminologi frasa secara khusus dilakukan oleh para linguis Barat yang mengkaji gramatika Arab atau linguis Arab yang membaca gramatika Arab dalam perspektif linguistik umum. Judul frasa dipilih sebagai subbab pembahasan dalam referensi gramatika seperti Modern Arabic Structure, Functions, and Varieties karya Holes, A Reference Grammar of Modern Standard Arabic karya Ryding, dan Modern Written Arabic A Comprehensive Grammar karya Badawi dkk. Selain referensi gramatika, kamus istilah linguistik juga memberikan istilah frasa dalam bahasa Arab. Al-Khuli (1982: 215) menyebut frasa dalam bahasa Arab dengan istilah 'ibārah dan syibhu jumlah atau syibjumlah dengan penjelasan komposisi kata yang tidak membentuk relasi subjek predikat.

Penelitian ini membahas tentang frasa verba nomina $(\mathrm{FVN})$ dalam bahasa Arab dalam kaitannya dengan bentuk dan perilakunya pada tataran sintaksis. Sebutan FVN sejauh pengamatan penulis sebenarnya belum digunakan oleh para linguis dalam literatur kebahasaan. Dalam literatur gramatika Arab modern, jenis FVN menjadi bagian frasa nomina (noun phrase) jenis idhäfah (genitive construct atau annexation structure) yang tersusun dari dua kata nomina atau lebih. Penulis memilih mengklasifikasi jenis ini secara tersendiri dengan pertimbangan adanya sejumlah karakteristik baik secara 
bentukdan perilaku dalam jenis frasa ini. Karakteristik bentuk dan perilaku ini diangkat sebagai permasalahan dalam pembahasan penelitian ini.

Penelitian tentang VN dan frasa nomina dalam bahasa Arab sudah pernah dilakukan oleh para peneliti, diantaranya:

1. Khodijah (2013) meneliti bentuk VN dalam tesis Verba Nomina (Mashdar) Sama'iy Fi'il Tsulatsi Mujarrad: Kajian Morfologi. Hasil penelitiannya menyimpulkan, Pertama, karakter pembentukan nomina verba fi'il tsulatsi mujarrad berdasarkan sistem akar dan pola. Integritasi akar dan pola akan membentuk nomina utuh yang memiliki makna leksikal dan gramatikal. Kedua, Nomina verba fi'il tsulatsi mujarrad terbagi menjadi dua yaitu nomina verba qiyāsiy dan nomina verba $s a m \bar{a} ' i y$. Nomina verba samā'iy menjadi fokus utama dalam proses morfologis. Nomina ini terdiri dari dua jenis, yaitu lazim dan muta'addi. Ketiga, nomina verba samā'iy digunakan dalam dua konteks, yakni pembuatan atau penggunaan bentuk kata yang didasarkan pada apa yang biasa digunakan dan didengar langsung dari orang Arab yang dinilai fashih, dan penggunaan metode pembakuan kaidah melalui proses penelusuran, penyimakan, pencatatan langsung dari fushaha' al-Arab.

2. Fitriyah (2013) melakukan investigasi salah satunya tentang VN yang berperilaku verba dalam tesis yang berjudul Nomina Berperilaku Verba dalam Bahasa Arab: Analisis Morfosintaksis. Dalam tesisnya, peneliti mengungkap proses morfologi dan peranan nomina tersebut di dalam tataran kata. Diantara hasil penelitiannya yang terkait VN adalah terdapat sejumlah bentuk dalam proses morfologi VN, yaitu al-mashdar alashlī, mashdar at-taukīd, mashdar almarrah, mashdar an-nau', al-mashdar al-mìmī, dan al-mashdar ash-shinā $\grave{\imath}$. Sedangkan terkait perilakunya, VN bisa berperilaku seperti verba, baik berupa verba transitif atau intransitif.

3. Ubaidillah (2008) meneliti tentang frasa nominal Bahasa Arab dalam tesis berjudul Kesalahan Pembentukan Frasa Nominal Bahasa Arab oleh Mahasiswa Jurusan Bahasa dan Sastra Arab Fakultas Adab UIN Sunan Kalijaga Yogjakarta. Temuan penelitian yang dihasilkan yaitu dalam pembentukan frasa nominal berstruktur $\mathrm{N}+\mathrm{N}$ kesalahan yang sering terjadi adalah penggunaan partikel pada unsur pertama, sedangkan pada frasa nominal berstruktur $\mathrm{N}+$ Adj kesalahan yang banyak dilakukan adalah pelesapan artikel pada unsur pertama yang bermarkah takrif. Faktor gramatika berupa perbedaan kaidah bahasa Arab dan bahasa Indonesia ditemukan sebagai alasan yang melatarbelakangi kesalahan pembentuan frasa nomina ini. Pembentukan frasa nomina bahasa Arab dengan struktur $\mathrm{N}+\mathrm{N}$ tidak boleh menggunakan artikel pemarkah takrif pada unsur pertama, sedangkan pada frasa nomina berstruktur N+Adj harus memperhatikan konkordansi dalam pemakaian pemarkah takrif.

Penelitian ini bertujuan mengungkap konstruksi FVN dan unsurunsur pembentuknya serta mendeskripsikan perilaku FVN dalam tataran sintaksis. Untuk dapat melaksanakan tujuan tersebut, penelitian ini dirancang menggunakan tiga tahap penelitian. Pertama, tahap pengumpulan data dilakukan dengan cara pengamatan secara langsung atau observasi objek penelitian. Data yang berupa kalimat yang memuat FVN dibaca, ditandai, dan dicatat dari sejumlah sumber data seperti AlQuran Al-Karim, teks hadis Nabi Muhammad, dan media surat kabar online. Kedua, tahap analisis data. Pada tahap ini digunakan metode distribusional yang mendasarkan cara kerjanya atas perilaku atau tingkah laku satuan-satuan lingual tertentu yang dianalisis dalam hubungannya dengan satuan-satuan 
lingual lainnya. (Djajasudarma, 1993:6061) Tahapan ketiga adalah penyajian hasil penelitian. Metode yang digunakan adalah metode formal dan informal.

Teori yang digunakan sebagai piranti analisis penelitian ini adalah teori sintaksis VN. Ryding dan Holes menggunakan istilah verbal noun untuk menunjuk kategori mashdar dalam bahasa Arab. Ryding (2005:75) menyatakan VN menunjuk kepada situasi atau tindakan yang ditunjukkan oleh verba seperti VN Jوwushūl "kedatangan" menunjuk makna tindakan yang ditunjukkan oleh verba وصwashala "datang". Holes (2004:146) lebih jauh membandingkan makna VN dalam bahasa Arab dengan verba infinitif atau gerund dalam bahasa Inggris. Hasil yang ditemukan adalah bahwa keduanya memiliki kesamaan semantik, yaitu menunjuk makna tindakan yang nyata terjadi (it was mistake to kill him) atau masih bersifat kemungkinan (they tried to kill him); atau menunjuk proses tindakan (writing is fun) atau hasil dari tindakan (I don't like his writing). Kalimat-kalimat tersebut dapat dialihbahasakan ke dalam bahasa Arab كان من الخطأ dengan makna yang sama, yaitu كان يماول كان كان

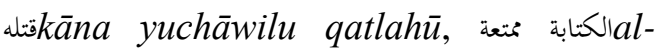
$\overline{k i t a ̄ b a t u ~ m u m t i ~ a t u n, ~ ا ٔ ح ب ~ ك ت ا ب ت ه ~}$ uchibbu kitābatahū.

Hassan (2001: 95) menyebut VN dengan istilah ism al-chadats yang berarti nomina yang menunjukkan tindakan, peristiwa, atau situasi yang ditunjukkan oleh bentuk verba. Dalam tradisi gramatika Arab, ciri pembeda verba dan VN secara semantik adalah unsur temporal. Semantik verba mengharuskan adanya unsur waktu sebagai makna inheren verba. Jika unsur ini hilang maka kategori verba bergeser kepada VN yang juga ditandai oleh pergeseran bentuk. Penjelasan ini didasarkan pada pendapat Ibnu Malik dalam Syarch Ibni 'Aqīl (1980: III/169) dalam Alfiyah: "Mashdar (VN) adalah nomina yang menunjukkan makna verba tanpa diikuti makna waktu seperti amnin (keamanan) dari verba amina (telah aman)".

Sebagai satuan kebahasaan, FVN memiliki struktur $\mathrm{N}+\mathrm{N}$ dengan $\mathrm{N} 1$ berkategori VN. Dalam bahasa Arab, frasa ini masuk kategori frasa nomina jenis idhäfah (construct state, annexation structure) dan mendominasi secara luas konstruksi frasa bahasa Arab. Ryding (205; Holes, 2004:204; Badawi, 2016:153) menyatakan N1 (mudhāf) harus bebas dari artikel definit (alif lam) atau tanwin (vokal yang berakhiran konsonan $\mathrm{n} /$ nunation) karena N1 dalam frasa ini ditentukan pemahamannya oleh N2 (mudhāf ilaih). Akan tetapi, sebagai nomina kepala, N1 bebas berada pada posisi nominatif ( $r a f a ')$, akusatif (nashab) dan genitif (jarr) berdasarkan fungsi dan kedudukannya dalam kalimat. Sedangkan N2 selamanya dalam posisi genitif, baik berkategori definit atau indefinit.

Kontruksi frasa idhäfah ini secara semantik gramatikal menunjukkan relasi antara N1 yang berkategori indefinit dan N2 yang berkategori definit atau indefinit. N2 berperan sebagai pewatas kemutlakan makna N1 (Hasan, 1987:III/2). Pewatas atau taqyìd ini memiliki banyak tipe relasi yang berbeda satu dengan yang lain. Ryding (2005:206) merincinya sebanyak 11 tipe relasi, yaitu 1. Relasi identitas 2 . Relasi posesif 3. Relasi parsial 4. Relasi agentif 5. Relasi obejktif 6. Relasi komposisi 7. Relasi ukuran 8. Relasi konten 9. Relasi tujuan 10. Relasi judul 11. Relasi klausa.

Dari sebelas tipe relasi tersebut, FVN memiliki relasi semantik gramatikal berupa relasi agentif dan relasi objektif. Tipe relasi ini bersandar pada keberadaan VN yang berperilaku seperti verba (ya'malu 'amala al-fi' $l i$ ) dalam gramatika Arab. Perilaku ini mengharuskan adanya unsur nomina yang berada setelah nomina berperilaku verba sebagai unsur yang melengkapi pemaknaannya. Dan diantara nomina tersebut adalah VN. 


\section{PEMBAHASAN}

\section{Bentuk FVN}

Bentuk FVN terdiri dari komposisi $\mathrm{N} 1+\mathrm{N} 2$ dengan $\mathrm{N} 1$ berkategori VN. Berdasarkan ketentuan umum yang berlaku dalam gramatika bahasa Arab, N1 harus berkategori nomina indifinit, tidak berprefiks alif lam atau bersufiks tanwin. Tanda baca fungsional ( $i$ 'rāb) N1 mengikuti fungsi dan kedudukannya dalam kalimat. Jika dalam keadaan nominatif, tanda baca fungsionalnya berupa dammah, keadaan akusatif bertanda baca fatah, keadaan genitif bertanda baca kasrah. Adapun N2 yang dapat berkategori nomina difinit dan indifinit selalu dalam keadaan genitif dengan tanda baca kasrah atau fatah atau ya' sesuai ketegori nominanya. Perhatikan kutipan ayat berikut:

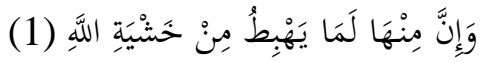

Wa inna minhā lamā yahbithu min khasyyati Allāh

"Dan diantaranya sungguh ada yang meluncur jatuh, karena takut kepada Allah". (QS. AlBaqarah:74)

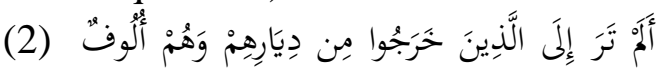
حَذَرَ الْمَوْتِ

Alam tara ilā alladzīna kharajū min diyārihim wahum ulūfun chadzara al-maut

Apakah kamu tidak memperhatikan orang-orang yang ke luar dari kampung halaman mereka, sedang mereka beriburibu (jumlahnya) karena takut mati (Qs. Al-Baqarah:243)

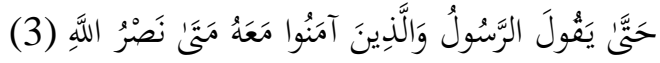
Chattā yaqūla ar-rasūlu wa

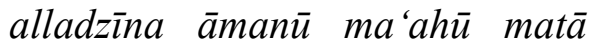
nashru Allāhi
Sehingga berkatalah Rasul dan orang-orang yang beriman bersamanya: "Bilakah datangnya pertolongan Allah?" (QS. AlBaqarah:241)

N1 FVN pada tiga data di atas berkategori VN, secara berurutan yaitu khasyyah (takut), chadzar (waspada), dan nashr (pertolongan). Ketigatiganya berasal dari verba trilateral khasyiya (takut), chadzara (waspada), dan nashara (menolong). Pada data (1) N1 bertanda fungsional kasrah dalam keadaan genitif sebab adanya preposisimin. Dengan mengacu pada preposisi ini, konstruksi tersebut dapat pula disebut sebagai frasa preposisional. Pada data (2) N1 berkedudukan akusatif dengan tanda fungsional fatah dan bermakna gramatikal sebagai keterangan argumentatif klausa verba kharajū (mereka keluar). Sedangkan N1 pada data (3) bertanda baca fungsional dammah dalam keadaan nominatif sebagai subjek dalam kalimat tanya. Adapun N2 pada tiga kutipan ayat di atas kesemuanya adalah dalam keadaan genitif bertanda baca fungsional kasrah.

Dapat dicermati pula, pada data (2) N2 berkategori VN yaitu kata almaut bentuk VN dari verba māta yamūtu. Hal ini mengindikasikan bahwa selain menempati N1, VN dapat juga menempati N2. Contoh lainnya adalah sebagai berikut:

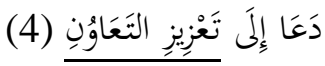

Da 'à ilà ta 'zìzi at-ta 'āwuni

Dia menyerukan untuk memperkuat kerjasama

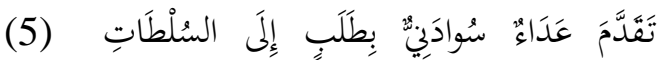
لِلْحُصُولِ عَلَى حَقِّ اللُجُوِْ فِنِ بِرِطَانِيَا 
Taqaddama 'adā'un Sūdāniyyun bithalabin ilā as-sulthāt li al-chushūl 'alā chaqqi al-lujū'

\section{fi Brìthāniyā}

Pelari Sudan mengajukan permohonan memperoleh hak suaka di negara Inggris (www.bbc.com)

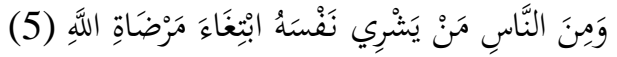
wa min an-nāsi mas yasyrī nafsahū ibtighā'a mardhāti Allāhi

Dan di antara manusia ada orang yang mengorbankan dirinya karena mencari keridhaan

Allah (QS. Al-Baqarah:207)

Komposisi FVN yang menggabungkan $\mathrm{N} 1+\mathrm{N} 2$ mengharuskan ketiadaan sisipan partikel preposisi yang biasanya mengikuti bentuk verba berpreposisi. Preposisi yang mengikuti verba berpreposisi ini juga akan muncul pada bentuk VNnya. Hal ini dapat diperhatikan dalam contoh-contoh berikut:

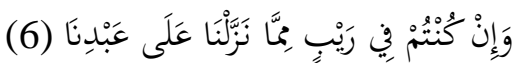

Wa in kuntum fi raibin mimmā nazzalnā 'alā 'abdinā

Dan jika kalian dalam keadaan meragukan atas apa yang telah Kami turunkan kepada hambaKami (QS. Al-Baqarah: 23)

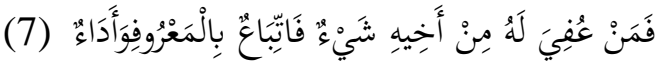

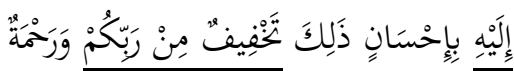

Faman 'ufiya lah̄̄ min akhīhō syai'un fattibā'un bi al-ma 'rū fi wa adā'un ilaihi bi ichsān dzālika takhfifun min rabbikum wa rachmah.

Maka barangsiapa yang mendapat suatu pemaafan dari saudaranya, hendaklah (yang memaafkan) mengikuti dengan cara yang baik, dan hendaklah (yang diberi maaf) membayar (diat) kepada yang memberi maaf dengan cara yang baik (pula). Yang demikian itu adalah suatu keringanan dari Tuhan kamu dan suatu rahmat. (QS. AlBaqarah: 178)

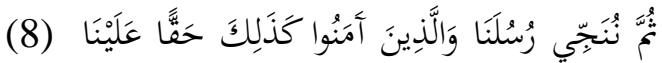

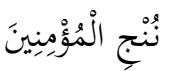

Tsumma nanjj̄̄ rusulanā walladzīna āmanū kadzālika chaqqan 'alainā nunji al-mu'minìn.

Kemudian Kami selamatkan rasulrasul Kami dan orang-orang yang beriman, demikianlah menjadi kewajiban atas Kami menyelamatkan orang-orang yang beriman. (QS. Yūnus: 103)

VN yang terdapat pada tiga kutipan ayat di atas tidak membentuk FVN sebab konstruksinya tidak berpola $\mathrm{N} 1+\mathrm{N} 2$, tetapi $\mathrm{N} 1+\mathrm{Prep}+\mathrm{N} 2$ yang secara berurutan yaitu, raibin $+m i n+m \bar{a} ; \quad$ fattibā'un $+b i+a l-$ ma' $r \bar{u} f, \quad \bar{a} d \bar{a}$ 'un $+i l \bar{a}+h \bar{\imath}$, takhfifun +min +rabbikum;

chaqqan+'alā $+n \bar{a}$. Sisipan preposisi antara N1 dan N2 menjadikan konstruksi tersebut tidak menjadi bagian dari kontsruksi idhāfah yang menjadi syarat adanya FVN. Konstruksi tersebut lebih tepat dikategorikan sebagai frasa preposisional.

\section{Perilaku FVN}

Istilah perilaku dalam sub judul tersebut lebih dimaksudkan sebagai fungsi dan peran masing-masing unsur yang terdapat dalam FVN. Unsur-unsur tersebut adalah VN sebagai N1 atau $m u d h \bar{a} f$ dan nomina atau VN sebagai N2 atau mudhäf ilaihi. Seperti yang telah dikemukakan sebelumnya bahwa VN adalah kategori nomina yang memiliki perilaku seperti verba. Perilaku ini didasarkan atas makna VN yang sebetulnya bermakna verba, yakni menunjukkan situasi, peristiwa, dan 
tindakan. Dalam gramatika Arab, perbedaan keduanya terletak pada unsur makna temporal. Verba mengungkapkan makna temporal sebagai unsur inheren, sedangkan VN tidak mengungkap makna tersebut.

Berpijak pada perilaku semantik verba, relasi yang dibangun VN dalam FVN adalah relasi agentif dan objektif. (Ryding, 2005:207). Relasi agentif dimaksudkan bahwa N2 atau mudhāf ilaihi berperan sebagai pelaku atau agen atas peristiwa, situasi, atau tindakan yang diungkap oleh VN. Dalam konstruksi klausa verba, konstruksi ini menempati fungsi subjek predikat. Adapun relasi objektik bermakna N2 atau mudhāf ilaihi berperan sebagai sasaran atau objek bagi makna VN. Contoh relasi agentif FVN adalah sebagai berikut:

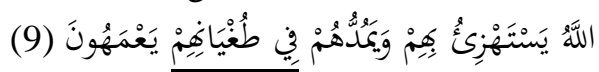
Allāhu yastahzi'u bihim wayamudduhum fì thughyānihim ya'mahūn

Allah akan (membalas) olok-olokan mereka dan membiarkan mereka terombang-ambing dalam kesesatan mereka. (QS. Al-Baqarah: 15)

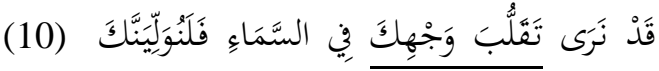

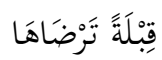

Qad narā taqalluba wajhika fi assamā' falanuwalliyannaka qiblatan tardhāhā

Sungguh Kami (sering) melihat mukamu menengadah ke langit, maka sungguh Kami akan memalingkan kamu ke kiblat yang kamu sukai. (QS. Al-Baqarah: 144)

وصول رئيس الوزراء إلى القاهرة بعد رحلة علاج (111) بألمانيا

Wushūlu ra'īsi al-wuzarā'I ilā alQāhirah ba'da richlati iiläjin bi Almāniya

Tibanya Perdana Menteri di Kairo setelah perjalanan medis di Jerman. (www.elwatannews.com)

Data (9) memuat FVN berupa thughyāni+him yang berkedudukan genitif oleh preposisi $f i$. N1 adalah bentuk VN dari verba thagh $\bar{a}-y a t h g h \bar{a}$ (lalim dan sewenang-wenang), sedangkan N2 adalah pronomina persona orang ketiga jamak. Konteks frasa ini menunjukkan bahwa N2 (him) berperan sebagai pelaku (agent) makna VN. Jika frasa ini dikonversi ke klausa verba akan menjadi l bighaghā dengan pronominal berkedudukan nominatif. Data (10) juga menunjukkan relasi agentif FVN yang terdapat pada konstruksi taqlluba wajhika. Berfungsi sebagai objek verba narā, kata taqalluba adalah bentuk VN dari verba taqallabayataqallabu (menengadahkan berulangulang wajah ke atas). Konteks frasa menunjukkan bahwa N2 wajhika berperan sebagai pelaku verba taqallaba yang berkategori verba intransitif sehingga tidak dimungkinkan adanya relasi objektif pada frasa tersebut. Situasi ini sama dengan data (11) yang memuat FVN dalam konstruksi wushūlu ra'īsi alwuzarā'i. Relasi agentif pada frasa ini tidak bisa digantikan oleh relasi yang lain sebab verba washala-yashilu berkategori intransitif.

Relasi agentif ini dapat menyebutkan unsur objek di luar konstruksi FVN. Penyebutan ini banyak terjadi dalam struktur frasa. Perhatikan kutipan berikut:

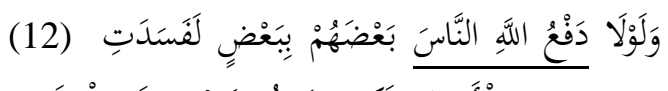

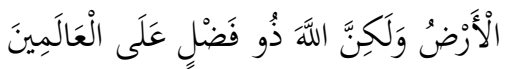

Walawlā daf'u Allāhi an-nāsa ba'dhahum biba'dhin lafasadati alardhu walākinna Allāhu dzū fadhlin 'alā al-'ālamīn

Seandainya Allah tidak menolak (keganasan) sebahagian umat manusia dengan sebagian yang lain, pasti rusaklah bumi ini. Tetapi Allah mempunyai karunia (yang dicurahkan) atas semesta alam (QS. Al-Baqarah: 251)

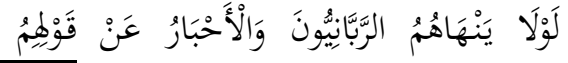

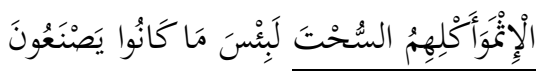

Lawlā yanhāhumu ar-rabbāniyyūna wa al-achbāru 'an qaulihimu al- 
itsma wa aklihimu as-suchta labi'sa mā kānū yashna' 'ūn.

Mengapa orang-orang alim mereka, pendeta-pendeta mereka tidak melarang mereka mengucapkan perkataan bohong dan memakan yang haram? Sesungguhnya amat buruk apa yang telah mereka kerjakan itu (QS. Al-Mā'idah: 63).

وذلك بعد أيام على إعلان عنان نيته الترشح (14) رسميا للانتخابات الرئاسية المقبلة

Wadzālika ba'da ayyāmin 'alā i'lāni 'Anān niyyatahu attarasysyucha rasmiyyan lilintikhābāti ar-ri'āsiyyati almuqbilati

Hal itu terjadi beberapa hari setelah Anan mengumumkan secara resmi rencana maju dalam Pilpres yang akan datang. (https://arabic.cnn.com)

Data (12) memuat FVN dengan relasi agentif yaitu konstruksi daf'u Allāhi. VN $d a f^{\prime} u$ berasal dari bentuk verba transitif dafa' $a$-yadfa' $u$ (menolak). Relasi ini kemudian menghendaki adanya objek di luar konstruksi FVN, yaitu kata an-nas $\bar{a}$ yang berperan sebagai sasaran makna tindakan "menolak". Karena di luar konstruksi FVN, objek tersebut berkedudukan akusatif, bukan genitif seperti mudhāf ilaihi. Sehingga pola yang dapat disimpulkan adalah $\mathrm{N} 1+\mathrm{N} 2+\mathrm{N} 3(\mathrm{Obj})$. Hal yang sama terjadi pada data (13) yang memuat dua konstruksi FVN relasi agentif yaitu qaulihimu dan aklihim dengan VN berupa qaul (dari verba transitif qāla-yaqūlu "berkata") dan akl (dari verba transitif akala-ya'kulu "makan"). Kedua nomina verba ini disandarkan pada mudhāf ilaihi berupa pronomina ketiga persona maskulin jamak yang berperan sebagai pelaku (agen), sedangkan objek sasaran dua tindakan tersebut adalah kata al-itsma dan as-suchta berkedudukan akusatif di luar konstruksi FVN.

Data (14) menyajikan dua FVN relasi agentif dengan menyebutkan objek di luar konstruksi frasa secara kompleks. Frasa pertama adalah i'lani 'Anān dan frasa kedua adalah niyyatahu. VN pada dua frasa tersebut adalah kata $i$ 'lāni (dari verba transitif a'lana-yu'linu "mengumumkan") yang disandarkan kepada 'Anān (proper name), dan kata niyyata (dari verba transitif nawā-yanwī "berniat") yang disandarkan kepada pronominal ketiga persona maskulin tunggal. Konstruksi frasa pertama dan kedua bersifat kompleks karena frasa pertama menghendaki adanya objek yang menjadi sasaran tindakan "mengumumkan" yaitu frasa niyyatahu yang berkedudukan akusatif. Objek yang berupa frasa ini memiliki konstruksi FVN relasi agentif yang juga menghendaki objek sasaran tindakan "berniat" yaitu kata at-tarasysyucha yang berkedudukan akusatif. Dalam situasi kompleks seperti ini, penting sekali untuk memperhatikan fungsi dan relasi masing-masing unsur sehingga masing-masing dapat dipahami sesuai konteks kalimat yang seharusnya. Dari sekian unsur pembentuk frasa dan unsur lain yang terkait, unsur yang inti terletak pada VN yang berperilaku seperti verba. Jika verba tersebut bervalensi dua unsur maka kedua unsur tersebut dapat disebutkan setelah VN, demikian juga jika bervalensi tiga unsur. Untuk dapat menentukan fungsi masing-masing unsur, konstruksi frasa harus jelas menunjuk masing-masing fungsi dengan adanya konteks kalimat yang menyertai, sebagaimana yang ditunjukkan oleh data (14) tersebut.

Relasi kedua yang dibangun oleh FVN adalah relasi objektif, yaitu relasi yang menghendaki N2 atau mudhäf ilaihi berperan sebagai sasaran tindakan yang diungkap oleh N1 atau mudhäf. Dalam literatur gramatika Arab klasik, relasi ini disebut idhāfatu al-mashdar ilā maf'ūlihi (menyandarkan mashdar kepada objeknya). Relasi ini menurut asumsi penulis adalah relasi yang dekat dengan struktur frasa verba bahasa Indonesia seperti frasa membaca komik, menolong fakir miskin, menulis novel. Berikut contoh-contoh FVN relasi objektif: 


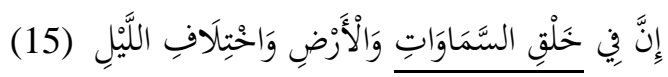

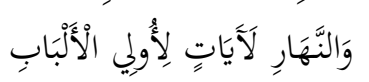

Inna fì khalqi as-samāwāti wa alardhi wakhtiläfi al-laili wan-nahāri la 'āyātin liulī al-albāb.

Sesungguhnya dalam penciptaan langit dan bumi, dan silih bergantinya malam dan siang terdapat tanda-tanda bagi orangorang yang berakal. (QS. Âli Imrān: 190)

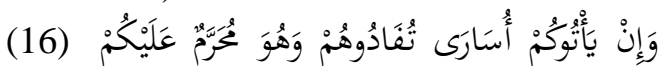

\section{إِخْرَابُجُهُمْ}

Wa'in ya'tūhum usārāa tufādūhum wahuwa mucharramun 'alaikum ikhräjuhum.

jika mereka datang kepadamu sebagai tawanan, kamu tebus mereka, padahal mengusir mereka itu (juga) terlarang bagimu (QS. AlBaqarah: 85)

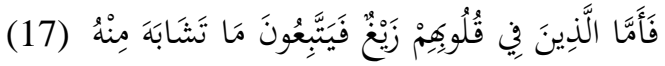

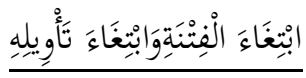

Fa'amma alladziña fì qulūbihim zaighun fayattabi'ūna mā tasyābaha minhu-btugnā'a alfitnati wabtighā'a ta'wīlih.

Adapun orang-orang yang dalam hatinya condong kepada kesesatan, maka mereka mengikuti sebahagian ayat-ayat yang mutasyaabihaat daripadanya untuk menimbulkan fitnah untuk mencari-cari ta'wilnya (QS. Āli Imrān: 7)

Data (15), (16) dan (17) di atas menyajikan konstruksi FVN relasi objektif dalam tiga fungsi gramatikal yang berbeda, yaitu genitif, nominatif dan akusatif. Konstruksi frasa khalqi assamāwāti (penciptaan langit) menempatkan N2 sebagai peran objek tindakan penciptaan. Demikian juga dengan frasa ikhrājuhum (mengusir mereka) N2 berupa pronomina ketiga persona maskulin jamak sebagai objek tindakan mengusir, frasa ibtighā'a alfitnati (menimbulkan fitnah) N2 berupa
VN sebagai objek tindakan menimbulkan, dan frasa ibtighā'a ta'wìlih (mencari-dari ta'wilnya) N2 berupa FVN sebagai objek tindakan mencari-cari. Objek berupa FVN ini juga memiliki relasi objektif yang N2 berupa pronomina ketiga non persona maskulin tunggal.

Relasi objektif FVN ini dimungkinkan secara teori kebahasaan memunculkan fungsi subjek nominatif di luar konstruksi frasa. Situasi ini seperti yang terjadi pada relasi agentif yang memunculkan unsur objek akusatif di luar konstruksi frasa. Contohnya adalah (Hasan, 1987:III/219):

صيانة الحواس الشاب وديعة تنفعه فن شيخوخته (18) Shiyānatu al-chawāssi asy-syābbu wadī 'atun tanfa 'uhū fì syaikhūkhatihì Penjagaan seorang pemuda terhadap panca indera merupakan investasi yang bermanfaat untuk masa tua

Konstruksi FVN pada data (18) tersebut adalah shiyānatu al-chawāssi dengan perincian shiyānatu (dari verba transitif shāna-yashūnu "menjaga") sebagai N1 dan al-chawāssi sebagai $\mathrm{N} 2$ dengan menyandang peran sasaran tindakan menjaga. Kemudian disebutkan setelahnya kata asy-syābbu yang memiliki relasi gramatikal subjek VN. Relasi antar ketiga unsur ini secara jelas dapat ditunjukkan oleh makna semantik masingmasing sehingga tidak dikhawatirkan adanya ketaksaan makna gramatikal. Makna gramatikal tersebut akan semakin jelas jika dilakukan substitusi posisi menjadi shiyānatu asy-syābbi alchawāssa, FVN relasi agentif. Pola posisi yang mendahulukan subjek daripada objek dalam bahasa Arab lebih kuat secara makna daripada sebaliknya. Dengan alasan ini pula, sejauh investigasi peneliti, didapati keberadaan pola FVN seperti yang ada pada data (18) jarang ditemukan. Sebagian besar pola FVN yang menyebutkan unsur valensi verba secara utuh memiliki pola relasi agentif seperti pada data (12) - (14). Cotoh lain pola relasi objektif adalah : 
حج البيت من استطاع إليه سبيلا (19)

Chijju al-baiti mani-stathā'a ilaihi sabīlā

Berhaji ke Baitullah bagi orang yang mampu melakukan perjalanan. (HR. Bukhori Muslim)

Pada data (19) frasa chijju al-baiti memiliki relasi objektif antara kedua unsurnya. Relasi ini kemudian disempurnakan dengan menyebutkan unsur subjek tindakan berhaji yaitu ungkapan man-stath $\bar{a}^{\prime} a$ yang berkedudukan nominatif.

Dengan mempertimbangkan kedua pola FVN yang berelasi agentif dan objektif dengan menyebutkan setelahnya unsur penyempurna berupa objek atau subjek maka dengan yakin peneliti menyimpulkan bahwa gramatika bahasa Arab memiliki tingkat adaptasi dan ekspresi alternatif yang bervariasi sehingga memudahkan bagi penuturnya untuk memengolah kata dan merangkai kalimat sesuai konteks yang dibutuhkan.

\section{KESIMPULAN}

FVN dalam bahasa sesungguhnya bagian dari frasa nomina (noun phrase) jenis idhāfah (genitive construct atau annexation structure) yang tersusun dari dua kata nomina atau lebih. Penelitian ini membuktikan bahwa FVN memiliki karakter tersendiri yang membedakan dari frasa nomina berkonstruksi genitif secara umum sehingga dapat menduduki tempatnya tersendiri. Pembuktian ini dilakukan melalui identifikasi bentuk dan perilaku sintaksis FVN. Bentuk FVN tidak bisa lepas dari bentuk frasa nomina berkonstruksi genitif yang dibangun dari unsur $\mathrm{N} 1$ berupa $\mathrm{VN}$ indefinit dan $\mathrm{N} 2$ berupa nomina atau $\mathrm{VN}$ genitif. Sedangkan perilaku sintaksis frasa ini ditandai dengan adanya relasi agentif dan objektif di antara unsur pembangunnya. Relasi ini didasarkan pada fakta bahwa VN memiliki kesamaan perilaku dengan verba yang memiliki relasi agentif dan objektif dengan unsur valensinya. Pada relasi agentif seringkali FVN disempurnakan dengan menyebutkan unsur objek yang berperan sebagai sasaran tindakan VN. Sebaliknya juga berlaku pada relasi agentif tetapi dengan frekuensi penggunaan yang lebih rendah.

\section{DAFTAR PUSTAKA}

\section{Buku dan Tesis}

Al-Khuli, Muhammad Ali. 1982. A Dictionary of Theoretical Linguistics English-Arab. Beirut: Librairie Du Liban.

'Aqil, Ibnu. Editor: Muhammad Muhyiddin. 1980. Syarch Ibni 'Aqīl. Kairo: Dar Mishr.

Baalbaki, Ramzi Munir. 1999. Dictionary of Linguistic Terms. Beirut: Dār al-'ilmi li al-Malayin.

Badawi, Elsaid, Michael G. Carter dan Adrian Gully. 2016. Modern Written Arabic A Comprehensive Grammar. London: Routledge.

Djajasudarma, T. Fatimah. 1993. Metode Linguistik: Ancangan Metode Penelitian dan Kajian. Bandung: Eresco.

Fitriyah, Yulaechah. 2013. Nomina Berperilaku Verba dalam Bahasa Arab: Analisis Morfosintaksis. Tesis. Sekolah Pascasarjana Universitas Gadjah Mada Yogyakarta.

Hasan, Abbas. 1987. An-Nachwu Al-Wāfí. Kairo: Dar al-Ma'arif.

Hassan, Tammam. 2006. Al-Lughah Al'Arabiyyah Ma'nāhā wa Mabnāhā. Kairo: 'Alam alKutub.

Holes, Clive. 2004. Modern Arabic Structure, Functions, and 
Varieties. Washington D.C.: Georgetown University Press.

Khodijah. 2013. Verba Nomina (Mashdar) Sama'iy Fi'il Tsulatsi Mujarrad: Kajian Morfologi. Tesis. Sekolah Pascasarjana Universitas Gadjah Mada Yogyakarta.

Ryding, Karin.C. 2005. A Reference Grammar of Modern Standard Arabic. Cambridge: Cambridge University Press.

Ubaidillah. 2008. Kesalahan Pembentukan Frasa Nominal Bahasa Arab oleh Mahasiswa Jurusan Bahasa dan Sastra Arab Fakultas Adab UIN Sunan Kalijaga Yogjakarta. Tesis. Sekolah Pascasarjana Universitas Gadjah Mada Yogyakarta

Ya'īsy, Ibnu. Editor: Emil Badi‘ Ya'qub. 2001. Syarchu al-Mufashshal. Beirut: Dar al-Kutub al'ilmiyyah.

\section{Website} http://www.bbc.com/arabic/mobile/middle east/2012/07/120727_sudan_ol ympics_asylum.shtml. diakses 10 Februari 2018.

\begin{tabular}{|l|}
\hline https://www.elwatannews.com/news/detai \\
\hline \multicolumn{2}{|c|}{ ls/2861886 diakses 10 Februari } \\
\hline 2018 \\
\hline
\end{tabular}

\begin{tabular}{|c|}
\hline https://arabic.cnn.com/middle- \\
\hline east/2018/01/24/egypt- \\
\hline presidential-elections- \\
\hline candidates \\
\hline 2018 \\
\hline
\end{tabular}

